\title{
A pragma-rhetorical study of selected Pentecostal sermons in Nigeria
}

\begin{abstract}
This study examines persuasion and communicative intentions in Pentecostal sermons in Nigeria. Notwithstanding the high scholarly inputs in religious discourse, no single work has examined the devices employed to achieve persuasion and conviction as well as communicative intentions in Pentecostal sermons in Nigeria. This work examines twelve sermons of selected Pentecostal preachers in Nigeria by drawing insights from rhetoric and pragmatic act to account for persuasion and communicative intentions in the data. Findings reveal that preachers strategically deploy rhetorical question; direct address and direct command; metaphor; repetition and structural parallelism; and they develop convincing arguments through logic/reason. It is also revealed that preachers share experiences with their listeners and they assume divine role by speaking authoritatively to convince their listeners into accepting their propositions. Preachers perform pragmatic acts of asserting/stating, encouraging, assuring, directing, commanding, praising, etc. The study has further confirmed that Pentecostal sermons can be used for public mobilisation.
\end{abstract}

Keywords: communicative intention, Christian religious Pentecostal sermons, pragmeme, rhetoric, metaphor.

\section{Introduction}

The central place which religion occupies in religious societies like Nigeria makes it a matter of interest to virtually everybody in such societies. Probably, this is why Omotunde (2015: 85) writes that "Just like language, religion is an important aspect of culture found in every human society, no matter how remote". One of the various forms in which the Christian religious discourse is realised is sermon and it is considered as one of the most important areas of worship. Sermons belong to the persuasive genre and its role in information, education and instruction cannot be overstressed. As

1 Address for correspondence: Department of English Studies, Adekunle Ajasin University, Akungba-Akoko, Nigeria. E-mail: samuelakinwotu@gmail.com, samuel.akinwotu@aaua.edu.ng 
a form of religious discourse, it is a means of ideological persuasion, hence Adam (2017: 22) avers that religious texts "represent a type of persuasive discourse and, as such, both create and reflect ideology" and their goal is "to persuade the audience of the veracity of the Christian doctrine".

In religious cultures like Nigeria, the place of worship is not just a place for people to gather for spiritual events; it is a centre for economic, political and socially wellcoordinated discourse events. The audience in this communicative action are mostly of the same society/culture with the preacher who is the active participant employing both linguistic and pragmatic resources to achieve effective communication. The way religion is structured gives preachers the power to exercise authority over their congregation. In this social context, sermons afford the preachers a measure of power over their hearers/readers who are most likely less informed/educated in matters of religion. In spite of this, however, the success of a sermon depends largely on the extent of its persuasiveness. To this end, persuasive strategies are necessarily adopted by preachers to ensure that crucial points, ideas, as well as arguments are presented in a manner to achieve conviction. This paper focuses on different ways in which persuasion is realised in Christian religious sermons. It attempts to identify and categorise the rhetorical strategies and linguistic realisations of persuasion in the texts under examination. The paper also examines how credibility and intentionality are achieved/ maintained in Christian religious sermons.

\subsection{Literature review}

It is important to note that scholars have always shown interest in investigating religious discourse as seen in the volume of works in this domain. Existing studies include Donovan (1976) which examines the features and forms of language use in religious speeches. He points out that "religious language is affective because it affects people's feelings, enters into their imagination, influences their emotions and often gives the impression of conveying profound truth". Odebunmi (2006) examines the stylistics of religious electronic media adverts in Nigeria. He observes that religious adverts are characterised by lexico-semantic, morphological, syntactic and pragmatic features, marked peculiar religious connotations which have the tendency to deceive the listener and lure him/her to act to the benefit of the advertiser. Also, Olaniyan and Oyekola (2006) deploy stylistic tools to examine Muslim sermons in South-west Nigeria. They observe that Muslim sermons are preoccupied by themes such as fear of Allah, supremacy of Allah, immorality and so on projected through morphological, lexico-semantic, syntactic and rhetorical devices. Aladeyomi (2006) investigates the phonological features of electronic media sermons in Nigeria. Using the yardsticks of Standard Nigerian English, he observes that the preachers performed well but did not meet the requirement for acceptable international intelligibility. Taiwo (2006) accounts for tenor in 
electronic media Christian discourse in Nigeria. It focuses on the analysis of the role structure into which participants in the discourse fit and how this determines how they make and interpret meaning in the discourse. Adeyanju (2008) is a stylo-semantic study of season's greetings from Pastor Adeboye. He observes that Pastor Adeboye "skilfully manipulated linguistic and rhetorical resources to preach a coherent and soul stirring sermon to the members of his church via the New Year greeting card". Bankole and Ayoola (2014) examine the nature of propositions and how interpersonal relationships are created in a Christian magazine.

Rajtar (2012) focuses on gender representation in the discursive practices of the Jehovah's witnesses in the former East Germany. The paper examines how the egalitarian stance of the official state ideologies influences the perspectives and practices of Jehovah's witnesses on gender related issues. Saddhono (2012) focuses on the structure and features of discourse, the topics, speech acts and the language form and functions in Friday sermon in Surakarta. Again, Abdel and Eldin (2014) investigate the language use in Amr Khalid's Islamic sermons to uncover the ideological devices in the sermons using critical discourse analysis (CDA) approach. Omotunde (2015) examines the rhetorical devices in the letter to the Hebrews in the Holy Bible. The study identifies appeal to pathos, logos, and ethos, and the deployment of rhetorical questions, repetition and parallelism as persuasive devices in the text. Kim (2016) interrogates a dominant ideological position that excludes women from pastoral position. The paper examines the text of a religious scholar that assigns sovereign values to the interpretations that tend to propagate and legitimise this patriarchal church's policy. The study observes that religious beliefs and doctrines often hinge on debatable and subjective interpretations of biblical texts based on the assumed mental models by presenting implicit presuppositions as unchanging and unchallengeable truths. Willy and Mbakop (2018) account for the pragmatic functions of 'Amen' as used in two different religious trends, namely, mainstream Protestant Churches and Pentecostal Churches. They observe that apart from its use in traditional conclusion and gospel truth, New-Born Churches also employ it to maintain interpersonal relations and as power marker.

Although the above has shown that a lot of works exist on religious texts, the pragmatic and rhetorical resources involved in effective communication of intentions have not been adequately explored in Christian religious Pentecostal sermons. Therefore, the significance of the present study lays in its focus on the identification and discussion of the persuasive elements and the strategies to achieve conviction in Pentecostal sermons with a view to accounting for communicative intentions and how balance and effectiveness are maintained in selected sermons. 


\subsection{Research questions}

The research questions of the study are the following:

i. What are the linguistic and non-linguistic elements that make a piece of language persuasive?

ii. What do Pentecostal preachers do to make their sermons credible and potent enough to convince their addressees?

iii. What are the pragmatic functions of language use performed in Christian religious Pentecostal sermons?

\section{Methodology}

The data for this study were mainly drawn from selected sermons of three Pentecostal preachers in South-west Nigeria who are popular with wide audience from diverse linguistic, ethnic and social backgrounds which necessarily makes English to be the preferred language of their sermons. They are; Pastor E.A Adeboye, the General Overseer of the Redeemed Christian Church of God (RCCG); Pastor W.F. Kumuyi, the General Superintendent of the Deeper Christian Life Bible Church (DCLBC); and Bishop David Oyedepo, the President of the Living Faith Church (LFC). From over thirty sermons sampled, twelve (12) were selected (4 for each), based on their thematic focus. The list of the sermons is hereby provided under each preacher.

Pastor E.A. Adeboye

1. Put your trust in God

2. Born to be a blessing

3. The Almighty

4. Prosperity

Bishop D. Oyedepo

1. The greatest miracle

2. Seed time and harvest

3. The Exploits of faith

4. Covenant wealth
Pastor W.F. Kumuyi

1. The power of prayer and praise

2. Faith

3. Holiness in Christian daily living

4. Christian giving

Some of the sermons exist in electronic audio form while others are already published in books. The records containing the audios were bought from the media department of the churches while the books containing other sermons were bought from the bookshops. The researcher listened to the audios and transcribed them into the written mode. The books containing the sermons and the transcribed form were critically read and relevant aspects that reveal the discourse representations of persuasion, argumentation 
and the communicative intentions of the preachers were culled from the data and subjected to analysis.

\section{Theoretical orientation}

Pentecostal sermon is a social process which involves a preacher and his/her listeners in a communicative interaction. Usually, it is a one-way communication in which the preacher/speaker is the only active participant. Listeners are not usually allowed to talk, save on rare occasions of emotional outbursts eliciting interjective responses, and when the preacher wants them to respond to a yes or no question eliciting a chorus answer and so on. Even though sermons are strictly one way communication, interaction progresses on the interplay of shared grounds between speakers and listeners. Sermons belong to persuasive discourse hence; preachers deploy pragmatic and rhetorical resources to achieve effectiveness in communication. Therefore, a detailed analysis of Pentecostal sermons would require both pragmatic and rhetorical investigation of the arguments of the preachers to be able to distil the fine details of the communication process. The pragma-rhetorical model as conceptualised in this study involves deploying a combination of Pragmatic Act Theory and Rhetoric to account for the communicative intentions and the strategies for maintaining balance and effectiveness in communication in the selected Christian religious Pentecostal sermons. Thus, the analysis involves the identification and description of the discoursal and rhetorical elements, the strategies for sustaining arguments and, the pragmatic functions of the language use in the data. Studies in persuasive discourse basically require an exploration of the art of rhetoric and argumentation. Again, a theory of action such as Mey's pragmeme which recognises the place of context in discourse interpretation is also required to account for intentions in the selected sermons. Thus, while rhetoric and argumentation will identify and evaluate persuasion and logic in the selected sermons, pragmeme will examine speakers' intentions in them.

As noted earlier, the engagement of the principles of rhetoric in persuading the audience to act or think in a particular way in religious communication is noteworthy. Aristotle (1954) cited in Roberts (2010) defines rhetoric as "the faculty of observing in any given case the available means of persuasion". Persuasion involves a writer or speaker in the act of influencing an audience or a reader to adopt a belief or follow a course of action. To achieve persuasion, speakers often make use of language to appeal to their listeners' emotion and sense of reason. According to Aristotle (1926/1959), there are three general means of persuasion or rhetorical appeal (ethos, pathos and logos). Thus, persuasion can be achieved by the personal character of the speaker (ethos; when the listener is made to believe that the speaker is credible), by putting the audience into a certain frame of mind (pathos; when the listener is made to feel emotionally elated by the speech) and by the proof provided by the words of the speech itself 
(logos; when conclusions are reached through logical presentation of truths) (see also Roberts 2010: 8-9). To Aristotle, the success of an oration depends not only on how well it is able to arouse the emotions of the audience but also, on the argument itself; when it demonstrates or seems to be demonstrated that something is the case. Thus, an orator (e.g. a Pentecostal preacher) must be credible and he must possess the capacity not only to manipulate language to sway the minds and swell the heads of his/her listeners, but also to achieve conviction depending on the topic of the sermon.

Aristotle further points out three kinds of rhetorical speeches: deliberative, forensic and epideictic. In the deliberative kind of speech, the speaker either advises the audience to do something or warns against doing something. The forensic speech either accuses somebody or defends self or someone; while the epideictic speech praises or blames somebody, as it tries to describe things or deeds of the respective person as honourable or shameful (see Adegoju 2005). Preachers often deploy persuasive devices to influence the beliefs, attitudes and forms of behaviour of their audiences through a deliberate act of producing utterances that appeal to their emotions and their sense of reason. This means that effective persuasive endeavour involves some measure of argumentation. According to Van Eemeren and Grootendorst (2004: 1) argumentation is "a verbal, social, and rational activity aimed at convincing a reasonable critic of the acceptability of a standpoint by putting forward a constellation of propositions justifying or refuting the proposition expressed in the standpoint”.

Persuasion involves a speaker in the presentation of arguments in a manner to achieve conviction. Thus, persuasive and argumentative capabilities of the speaker are essential to the success of any argumentative endeavour. Since the aim of rhetoric and argumentation is to achieve persuasion and meaning in communication, a fusion of insights from rhetoric and dialectics frameworks will be beneficial to the understanding of an ordinary argumentation (see van Eemeren \& Houtlosser 2002; Eemeren \& Grootendorst 1984).This is so because, as a social activity, the making of a discourse involves that the speaker should present his/her views and opinions in such a manner that the audience will be persuaded to accept them. While it is important for a speaker to be persuasive in his/her presentation, the argument must also be logical and rational in order to convince the listeners. To a large extent, the success of a communicative enterprise depends largely on the ability of the arguer to make his/her standpoint convincing and conclusive.

The second theory adopted for this study is Pragmatic Act Theory (PAT) or Pragmeme. PAT is a development on J.L Austin's (1962) Speech Act Theory. Mey's disagreement with Speech act is not only the idea of speech act verbs (SAVs) but on its abstract idealization of the intentional speaker and hearer and not on social reality. He contends that not all speech acts have corresponding SAV; sometimes, they may be represented by several verbal items. Pragmeme is different from speech act since it depends essentially, on the 
circumstances that led to, and the situation in which the action takes place rather than the actual words being used. This implies that theory places premium on the sociocultural and societal factors in the construction and interpretation of meaning. It views communication as a dynamic process in which an individual is not only limited or constrained by societal conditions but he/she is also shaped by them at the same time. This means that the overall pragmatic meaning of an act is jointly determined by a combination of features of the context or situation of utterance in agreement with the rules entailed by such a situation or context. Capone (2005: 1357) describes pragmeme as:

a speech act -an utterance whose goal is to bring about effects that modify a situation and change the roles of the participants within it or to bring about other types of effect, such as exchanging/assessing information, producing social gratification or, otherwise, rights/obligations and social bonds.

As in the real world, situations are not permanent; they keep changing and bringing about other types of effects. This dynamic nature of the situation is a component of pragmeme which allows for modifications such as the changing or retention of the roles of participants to achieve variants of same act/effect or an entirely different one. Context and rules of language are essential features of pragmeme. By these, it is ensured that what is said and meant are within what the society allows (social constraints) in particular situations, subject to the rules of the language. Stressing the role of context, Mey (2001: 217) avers that, "no conversational contribution can be understood properly unless it is situated within the environment in which it was meant to be understood". Also, the rules of language provide the ground upon which what is said in context is systematically transformed into whatever is meant.

Pragmeme emphasises the societal and individual features in meaning construction and comprehension. Thus, an individual actor or participant operates within the affordances of his/her society and the rules of engagement of the language in use. According to Mey (2001: 219):

The theory of pragmatic acts does not try to explain language use from the inside out, from words having their origin in a sovereign speaker and going out to an equally sovereign hearer (...). Rather, its explanatory movement is from the outside in: the focus is on the environment in which both speaker and hearer find their affordances, such that the entire situation is brought to bear on what can be said on the situation, as well as on what is actually being said.

In Mey's opinion, human activity is not the privilege of the individual. Rather the individual is situated in a social context, which determines his/her affordances. 
This is a deterministic view that limits individual initiatives with respect to what an individual can say and what he cannot say. Mey explains further that no two situations in real life are ever the same, just as no two practs are ever the same with regard to the actual situation under which they are realised. At the same time, every pract is an allopract which is a variant of the same pract; a realisation of a particular pragmeme (Mey 2001: 221). Hence, Odebunmi (2008) submits that what determines a pract is solely participants' knowledge of interactional context. The relationship between a pract and an allopract can be likened to the relation of a general class and its sub-classes or types. In other words, a pract is the general class while an allopract is a type or variant of it. This is means that a pract includes all other variants (allopracts) of it. As a theory that emphasises the importance of participants' knowledge of interactional context in the understanding of meaning in any speech event, pragmeme is more appropriate for this study. This is especially so, because of its ability to harness the pragmatic resources to adequately account for the intentions of the preachers in the selected sermons.

\section{Data presentation and analysis}

Generally speaking, religious discourse is usually persuasive. As a type of public speech, it involves speakers in strategic presentation of their communicative intentions in a manner that will appeal to their listeners and as a result, accept their point of view. In this segment of the paper, the devices and/or strategies employed to achieve persuasion and conviction and the pragmatic functions of language use performed in the process are examined. The extracts below would serve the purpose of illustration and analysis

Extract (1) Are you under satanic bondage? Are your enemies oppressing you? Are you under the bondage of sin? The Almighty God is able to save to the uttermost.

(Sermon 1)

Extract (2) Adultery destroys your soul. You must be a fool of the highest order to indulge in adultery. For, adulterers and fornicators are enemies of themselves and they will not enter the kingdom of God unless they repent. Jesus is coming back again for a bride without spot, blemish or wrinkle. Today is your day of salvation; do not let it pass you by. (Sermon 1)

Extract (3) Whenever you pray and there is no answer, check your life. Sin is a barrier to answered prayers. You may hide your sins from your pastor but not from God. You cannot be living in sin and expect the grace of God to multiply in your life. Righteousness qualifies you for divine attention while sin disqualifies you. There is no rest for sinners. Repent today and enter into your rest. (Sermon 12)

Extract (4) Who is like unto thee oh God of heavens and earth! Your works are marvellous. There is none on earth who can stop the sun in its circuit or the moon from 


\section{Extract (5) We have enough reasons to thank our God. He is the eyes that watch us even in darkness, the ear that listens to our petitions, and the mercy that endures forever. Beloved, think of His love; think of His blessings; think of His miracles, signs and wonders in your life. You are alive today because He spares your life. He fights your battles for you and gives you victory. What more can you give Him. Go ahead and give Him praise! (Sermon 3)}

Extract (6) God commands us to praise him in all situations. When you have so much in your pocket, praise him; when you can hardly pay your bills, praise him; when you get a new job, praise him; when you have just received your sack letter, praise him. Thank him for food on your table, thank him for ability to eat it, thank him for sleeping and waking and thank him for everything. (Sermon 5)

Extract (7) The word of God is powerful. It is your seed for a miracle. When you plant a seed, you expect it to bear fruits and when you plant the word you expect a miracle. When you plant the healing word you reap healing miracle. Therefore, begin to speak to your situation now (Sermon 10)

Extract (8) Giving is getting. The more you give, the more you get. The more you invest in people through giving, and in the cause of God, the more you receive now and in eternity. (Sermon 8)

Extract (9) God is the owner of the earth and the fullness by creation. It does not matter the nature of your problem, He is able to deliver you from it. Life is a battle; it is full of challenges but our God is a great deliverer. All you need to do is to put your faith in him. Power to safe and deliver belongs to him. He is exceedingly great. (Sermon 6)

Extract (10) Do not put your trust in any man; such a man can travel or even die. God will never become tired. He will never fail you. He is the only friend who can go through the valley of the shadow of death with you. He is the only friend you can trust. (Sermon 7)

Extract (11) When God commands, it happens. He commanded and there was light. Absolute power belongs to God. God is greater than the greatest doctor and His power can save and cure even supposedly incurable diseases (Sermon 11)

Extract (12) Man was created by God to live forever; but death came into the life of man after the unfortunate incident in the Garden of Eden. Since then, man has to struggle in the midst of comfort, he became poor in the midst of abundance and finally, he must die for his sins. For, the wages of sin is death, but the gift of God is eternal life. Salvation is only possible through Jesus Christ. Give your life to Christ today and be saved. (Sermon 7) 
Extract (13) God is the sufficiency of all that trust Him. He is the present help to the helpless, the controller of the universe, the Everlasting One. When He opens the door, nobody can shut it. (Sermon 4)

\subsection{Use of rhetorical question}

One major persuasive element that is significant in the data for this study is rhetorical question. A rhetorical question is one that does not require the readers/listeners to answer/respond to it. Although it may sometimes, be framed in the nature or structure of a question, it is meant to be a statement. As revealed in the data, rhetorical questions are employed by preachers to make their listeners engage in self-reflection and by so doing, lead them into a premeditated conclusion. As can be seen in extract 1 , the questions are covert means of stating the problem which is followed immediately by the solution/suggestion/advice. The rhetorical questions state the problems (satanic bondage, oppression by enemies and bondage of sin) in succession. It is assumed here that participants have the shared contextual apriori experience (SSK) of these problems from which the listener desires deliverance and to which the speaker offers a solution in the concluding sentence (The Almighty God is able to save to the uttermost). This, perhaps, supports the choice of the present form of the verb 'to be' [is, (not was) able] which makes the statement free from time constraints. The statement that follows the rhetorical questions reveals the communicative intention of the preacher. This assertive statement is deployed to perform the pragmatic act of assuring. Through this, listeners are being encouraged to have faith in God and look up to Him for solution to, or deliverance from their problems.

\subsection{Use of direct address and direct command}

Pentecostal preachers often talk or address their listeners directly especially when they desire to establish close bond with them. This device comes in two distinct but sometimes interrelated forms, namely, direct address and direct command. Direct address and direct command involve the speaker in speaking directly to a listener in a manner that will attract his/her attention and to make him/her believe that the speaker cares or empathises with his/her situation. Even though direct address and direct command are usually engaged in face-to-face communication, they are also used in written communication, especially when the writer wants to persuade his/her listeners to accept a particular proposition. It should be noted however that, while direct address may serve the purpose of informing, advising or urging listeners to take a particular step or do something, a speaker may give an instruction, directive/command or make a request through direct command. As revealed in the data, direct address and direct command are achieved through some pronominal elements such as 'thee', 'you' and 'your' used to restrict the applicability of the statements to the addressees. For example, 
the preachers in extracts 2 and 3 used the second person pronoun 'you' and 'your' to connect with their listeners directly as if they are in personal/one-on-one interactions. Thus, they personalise the propositions to establish emotional link (bonding) with their listeners and legitimise themselves as a leader or one who knows better than them. Operating as a leader in extract 1 , the preacher asserts that "adultery destroys your soul" and warns his listeners collectively and individually, against the dangers of sin/adultery. He performs the pragmatic acts of asserting and warning. He also performs the pragmatic acts of advising/encouraging by commanding when he says "repent "today and enter into your rest". The last sentence in extract 5 and the phrase "praise him" repeated four times in extract 6 are direct commands and they also perform the pragmatic act of directing/instructing. Again in extract 4, the preacher addresses God directly using the pronouns thee, you and your to perform the pragmatic acts of praising, worshipping and adoring God while encouraging his listeners to do same.

\subsection{Use of metaphor}

Metaphor (MPH), which is a device for comparison, is employed to achieve persuasion in Pentecostal sermons as revealed in the data. In extracts 2 and 3 above, sin and righteousness are metaphorically and symbolically juxtaposed in a manner that establishes the logical connections between them. The lexical choices such as 'fool' and 'bride' are descriptive metaphor for sinners (adulterer and fornicator) and the righteous (without spot, blemish and wrinkle) respectively. While sin is presented metaphorically as a barrier and destroyer (Sin is a barrier..., Adultery destroys...), righteousness is symbolically presented as a "bride" [precious, favourable, priceless (Prov. 18:22 \& Prov. 31: 10)] without "spot, blemish, and wrinkle". The preacher leverages on the Shared Religious Knowledge (SRK) that Jesus is coming back again (John 14:3, Acts 1:11) to examine these two opposing religious concepts to persuade his listeners to accept his position. He performs the pragmatic act of warning (against living in sin)as well as the pragmatic act of encouraging righteous living (Righteousness qualifies you for divine attention while sin disqualifies you).

Another example of metaphor is in extract 5, where the preacher compares God to some sensitive and highly important and useful parts of the human body to underscore the importance and role of God in the life of man. God is compared to the 'eyes' that watch us even in darkness (protects/secures) and 'ear' that listens to our petitions (listens/hears). The first and second sentences of extract 7 are noteworthy in performing the pragmatic act of encouraging. Here, the preacher uses the metaphor of farming/ agriculture (planting and reaping/harvesting) to compare the process of receiving a miracle to harvesting/reaping in farming. He compares "the word of God" to the "seed" (plant/sow) while the "fruit" (harvest/reap) is the metaphor for a "miracle". This, perhaps, is to encourage the listeners that miracle is not a commonplace as may be perceived 
by the righteous ones. As in farming, there is the time of sowing with the expectation of a harvest. The analogy is used to perform the pragmatic act of encouraging.

\subsection{Use of repetition and structural parallelism}

Repetition and structural parallelism are also significant persuasive devices employed in Pentecostal sermons. While repetition occurs when an element is either repeated (partly or wholly) for emphasis, structural parallelism involves a deliberate repetition of structures to express related issues in order to show the similarities or differences in them. Examples in the extracts above include "mighty to" (4 times) in extract 4; "think of" (3 times) in extract 5; "the more you" (4 times) in extract 8; "when you" (4 times) and "thank Him" (4 times) in extract 6. The devices are also used in extract 7 to systematically present an argument. The phrases, "when you plant...” and "you expect...” structurally interlinked to achieve emphasis and clarity. So also in extract 8,giving and getting and, investing and receiving are logically and structurally juxtaposed. The paradox of the phrase, "giving is getting", can be better explained inter-textually with some biblical references:

(a) Give, and it shall be given unto you; good measure, pressed down, and shaken together, and running over, shall men give into your bosom. For with the same measure that ye mete withal it shall be measured to you again. (Luke 6: $38 \mathbf{~ K J V}$ )

(b) But this I say, He that soweth sparingly shall reap also sparingly; and he which soweth bountifully shall reap also bountifully. (2 Cor.9: 6 KJV)

The above biblical references establish the shared religious knowledge (SRK) of the principle of giving as a means to receiving supernatural abundance (the more you give/sow, the more you receive/reap) which the preacher activates to link the immediate situational experience (SSK) to perform the pragmatic act of inspiring and encouraging his listeners to give.

\subsection{Use of logic or reason}

Since the essence of persuasion is to achieve conviction, preachers usually make their argument logical and reasonable. They not only present their argument in a systematic order of input and output relation (logicality) but also provide the premise or basis for their goals/positions/perspectives. For example, the argument in extract 7 is logically connected through the sequential ordering of the phrases, when you plant" (input) and "you expect" (output).Also, in the first sentence of extract 2 (topic sentence), the preacher asserts that sin is destructive (Adultery destroys your soul). This assertion is strengthened by the sentences that follow where the preacher further reveals the consequences of adultery and fornication. Through tactical deployment of the rhetorical appeal 
of logos, he initiates his argument by stating the consequences (sentence 1-3) of indulging in sin and concludes by condemning and warning his listeners against sin (For, an adulterer and a fornicator is an enemy of himself and such will not enter the kingdom of God). The preacher performs the pragmatic acts of stating/asserting (Jesus is coming back again for a bride without spot, blemish or wrinkle). He also performs the pragmatic act of encouraging and advising his listeners to forsake sin and avoid its consequences (Today is your day of salvation; do not let it pass you by).

In extract 11, the preacher develops an argument and provides a reason or evidence to convince his listeners of the truth in his proposition. The proposition (When God commands, it happens.), is supported by an evidence that God is powerful (He commanded and there was light) which he legitimises in the last two sentences (God is greater than the greatest doctor and His power can save and cure even supposedly incurable diseases). He performs the pragmatic act of encouraging/assuring.

Pentecostal preachers also achieve conviction by providing the premise or basis for their goals/positions/perspectives. For example, in extracts 10 and 13, the preachers tactically provide the premise/basis for their goals to encourage or assure their listeners of the unfailing presence, power and influence of God and his readiness to help in solving their problems. Speaking directly to his listeners in extract 10, the preacher activates listener's SRK that "God is our refuge, and strength, a very present help in trouble" (Psalm 46:1 KJV) and encourages them to have faith and trust in God. He performs the pragmatic act of advising (Do not put your trust in any man) through a logical argument in which he compares God (a friend who can be trusted because he can never be tired and he can never fail) with man (who cannot be trusted because he can fail, travel or die). In the same vein, the preacher in extract 13 activates the listener's SRK about God's ability to provide for all their needs (The earth is the Lord's, and the fullness thereof; the world, and they that dwell therein. Psalm 24:1 KJV). He performs the pragmatic acts of affirming/stating, inspiring and assuring. While arguing that sin and grace are diametrical opposites, he justifies his position that sin is a barrier to answered prayers such that whenever they pray and there is no answer, they should examine their lives.

\section{Discussion and conclusions}

This study has examined the rhetorical resources and communicative intentions in Christian religious Pentecostal sermons in Nigeria. It has identified and discussed the significant persuasive resources and the devices and/or strategies used to achieve conviction and maintain balance and reasonableness in Christian Pentecostal sermons. The study has also accounted for the pragmatic functions of language use in the selected data.

This study has revealed that Pentecostal preachers tactically employ persuasive appeal of logos to develop clear and convincing arguments. As observed by Adam 
(2017: 20), appeal to rationality of the audience is a major means of achieving clarity which is at the heart of Aristotelian concept of logos and this can be facilitated by lexical means. In the data examined for this study, the preachers deploy lexical and rhetorical devices such as direct address, direct command, repetition, structural parallelism, rhetorical question and metaphor to facilitate the clarity of their message. To further achieve conviction, they present the basis/premise/reason for their proposition in the style of cause and effect or input and output relation. Also, the language of the preachers reveals shared experiences with their listeners. Quite often, Pentecostal preachers assume divine/institutional voice by speaking authoritatively on issues. This can be likened to what Bhatia (1999) and Hyland (2005) called 'credibility boosters'. In the case of our data, preachers employ this communicative mechanism to increase their credibility and to enhance the value of their message. In the course of preaching, they also make reference to specific passages or stories in the bible that are general/shared knowledge to their listeners and this helps in enhancing their status.

According to van Dijk (1998: 316-317), "discourse has a special function in the expression, implementation and especially the reproduction of ideologies, since it is only through language use, discourse or communication [...] that they can be explicitly formulated". Adam (2017) perhaps has this in mind when he claims that religious communication has the basic purpose of creating, mediating and reflecting ideology. One can therefore, glean from the above that apart from persuading the audience, Pentecostal preachers engage in teaching and they also use language to perform some actions or communicate their intentions. Some of the pragmatic functions of language use performed in the data include asserting/stating, encouraging, assuring, directing, commanding, praising, condemning, warning and disapproving to convince their listeners into accepting their propositions and act in a preconceived way.

In conclusion, it is evident from this study that persuasion is at the core of Pentecostal sermons which can be used for mobilising or demobilising listeners. To a large extent, Pentecostal preachers employ logical utterances embellished with quasi logical techniques of persuasion that are meant to achieve effectiveness in communication. They creatively use language to motivate and energise their audiences, and to earn their trust. The author believes that the findings of this paper will be of benefit to religious preachers in that it will help them to master the art effective religious communication. The findings will also be useful as pedagogical resources in language and communication. Further research can juxtapose the pragma-rhetorical resources in orthodox and Pentecostal movements within the Christian religion. 


\section{References}

Abdel, A. \& Eldin, T.S. 2014. Critical Discourse Analysis of religious sermons in Egypt - case study of Amr Khalid's sermons. International Education Studies Vol. 7, No. 11. URL: http://dx.doi.org/10.5539/ies.v7n11p68 www.ccsenet.org/ies

Adam, M. 2017. Persuasion in religious discourse: Enhancing credibility in sermon titles and openings. Discourse and Interaction. Assessed from: https://www. researchgate.net/ publication on $21 / 10 / 2020$

Adegoju, A. 2005. A Stylistic Study of the Speeches of Some Key Actors of the June 12 Crisis in Nigeria (1993-98) [Unpublished PhD Thesis], Department of English, University of Ibadan.

Adeyanju, D. 2008. Season's greetings from a cleric: A stylo-semantic analysis of pastor Adeboye's new year compliments. Papers in English and Linguistics (PEL) Vol 6, 85-94. Aladeyomi, S. A. 2006. Phonological features of electronic media sermons. In: A. Odebunmi \& O. Babajide Adeyemi (eds.), Style in Religious Communication in Nigeria. Germany: LINCOM.

Bankole, M. A. \& Ayoola, M.O. 2014. Mood and modality in Christian magazines: a systemic functional analysis of Christian Women Mirror. International Journal of Humanities and Social Science Vol. 4, No. 14: 138-149.

Bhatia, V. K. \& Bremner, S. (eds) 2014. The Routledge Handbook of Language and Professional Communication. London: Routledge.

Capone, A. 2005. Pragmeme (a study with reference to English and Italian). Journal of Pragmatics 37: 1355-1371.

Donovan, P. 1976. Religious Language. London: Sheldon Press.

Hyland, K. 2005. Stance and engagement: A model of interaction in academic discourse. Discourse Studies 7/2: 173-192.

Kim, E. J. 2016. Persuasive strategies in a chauvinistic religious discourse: the case of women's ordination. Critical Approaches to Discourse Analysis across Disciplines Vol 8 (1): 58-83.

Mey, J. 2001. Pragmatics: An Introduction. London: Blackwell.

Odebunmi, A. 2006. The stylistics of religious electronic media adverts in Nigeria. In: A. Odebunmi \& A. Babajide (eds.), Style in Religious Communication in Nigeria. Germany: LINCOM.

Odebunmi, A. 2008. Pragmatic strategies of diagnostic news delivery in Nigerian hospitals. Linguistik Online 36, 4/08: 21-37.

Olaniyan, K.K. \& Oyekola, A.G. 2006. A stylistic study of Muslim sermons. In: A. Odebunmi \& A. Babajide (eds.), Style in Religious Communication in Nigeria. Germany: LINCOM.

Omotunde, S. A. 2015. Rhetorical devices in the letter to the Hebrews in the Holy Bible. Ife Studies in African Literature and the Arts Vol. 40: 85-103. 
Rajtar, M. 2012. Gender in the Discursive Practices of the Jehovah's Witnesses in the former East Germany. Social Compass 59: 102-119.

Rapp, C 2002 Aristotle's Rhetoric. Stanford Encyclopaedia of Philosophy. http://plato.stanford.edu/entries/aristotle-rhetoric/

Roberts, W. R. 2010. Aristotle's Rhetoric and Poetics. New York: Random House Inc.

Saddhono, K. 2012. The discourse of Friday sermon in Surakarta: A socio-pragmatic study. Doi:10.17510/wjhi.v14i1.53. https://www.researchgate.net

Taiwo, R. 2006. Tenor in electronic media Christian discourse in Nigeria. In: A. Odebunmi \& A. Babajide (eds.), Style in Religious Communication in Nigeria. Germany: LINCOM. The Redeemed Christian Church of God 2012. (RCCG) at 60. The 60th Annual Convention Programme

van Dijk, T. A. 1998. Ideology. A Multidisciplinary Approach. London: Sage Publications. Van Eemeren, F.H. \& Grootendorst, R. 1984. Speech Acts in Argumentative Discussions. Dordrecht: Foris Publications.

Van Eemeren F. H \& Grootendorst, R. 2004. A Systematic Theory of Argumentation: the Pragmadialectical Approach. Cambridge: Cambridge University Press.

Van Eemeren F. H \& Houtlosser, P. 2002. Strategic manoeuvring: Maintaining a delicate balance. In: F.H. Van Eemeren \& P. Houtlosser (eds.), Dialectic and Rhetoric: the Warp and Woof of Argumentation Analysis, 131-159. Dordrecht: Kluwer Academic Publishers. Willy, A. \& Mbakop, N. 2018. A comparative analysis of the pragmatic functions of 'Amen' in mainstream Protestant and Pentecostal churches in Cameroon. Springer, Link: https://link.springer.com/article/10.1007\%2Fs41701-018-0032-4\#Sec1

$* * *$

Dr. Samuel Alaba Akinwotu is a senior lecturer in the Department of English Studies, Adekunle Ajasin University, Akungba-Akoko, Nigeria. His areas of research interest are Pragmatics and Discourse Analysis. He has published in both local and international journals. 